\title{
Heart transplantation: a history lesson of Lazarus
}

\author{
Sanjeet Singh Avtaar Singh ${ }^{1,3}$, Nicholas Banner ${ }^{2}$, Colin Berry ${ }^{3}$, Nawwar Al-Attar ${ }^{1}$ \\ 1Department of Cardiothoracic Surgery, Golden Jubilee National Hospital, Glasgow G81 4DY, UK. \\ ${ }^{2}$ Heart Failure and Mechanical Circulatory Support, Harefield Hospital, Harefield UB9 6JH, UK. \\ ${ }^{3}$ Institute of Cardiovascular and Medical Sciences, University of Glasgow, Glasgow G12 8QQ, UK.
}

Correspondence to: Sanjeet Singh Avtaar Singh, Department of Cardiothoracic Surgery, Golden Jubilee National Hospital, Glasgow G81 4DY, UK. E-mail: sanjeetsingh@nhs.net

\begin{abstract}
How to cite this article: Singh SSA, Banner N, Berry C, Al-Attar N. Heart transplantation: a history lesson of Lazarus. Vesse/ Plus 2018;2:33. http://dx.doi.org/10.20517/2574-1209.2018.28
\end{abstract}

Received: 7 May 2018 First Decision: 25 Sep 2018 Revised: 26 Sep 2018 Accepted: 26 Sep 2018 Published: 24 Oct 2018

Science Editors: Mario F. L. Gaudino, Cristiano Spadaccio Copy Editor: Cai-Hong Wang Production Editor: Zhong-Yu Guo

\begin{abstract}
One of the notable advances in modern day medicine is organ transplantation. None more so than the heart. A complex interaction between physiology, surgery and immunology that spanned decades, involving the hard work of many pioneers in their fields. We revisit the contributions of the pioneers as well as marvel at the paradigm shifts in medicine that have made heart transplantation safe and reproducible with in excess of 3000 transplants done yearly today.
\end{abstract}

Keywords: Heart transplantation, history, immunosuppression

\section{ORGAN TRANSPLANTATION AND ANCIENT HISTORY}

Organ transplantation is arguably one of the greatest feats of modern medicine of the past century. Initially stemming from historical experimentation, it has become a mainstay of treatment for many chronic conditions and continues to do so in spite of improvements in device technology. Organ donation however underwent several challenges initially with cultural acceptance, ethics and legality, and political pressure. It has since evolved with the merging of improvements in the donation-allocation-procurement process, advances in technology, refinement of surgical technique, scientific breakthroughs in organ preservation, cognitive and methodical improvements in immunology and immunosuppression alongside expertise in managing adherent complications of organ transplantation.

In ancient civilisations, the practice of removal of organ/tissues for a multitude of reasons (beautification or therapeutic) was initiated. Hindu texts from 3 millennia ago provide detailed accounts of skin grafting from

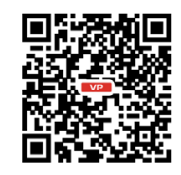


fatty regions (buttocks) or protrusions (chin) for reconstruction of mutilated noses incurred during wars or punishments ${ }^{[1]}$.

One of the earliest records of organ transplantation, Bian Que, a reported clairvoyant during Han Dynasty in Ancient China reportedly performed an exchange of hearts. He felt that the attainment of balance was possible by exchanging organs between men of "strong will" but "weak spirit" with that of one with opposite traits by intoxicating a "patient" with fortified wine prior to "cutting their breasts removing their hearts and applying numinous medicine" ${ }^{\text {"[2] }}$.

The New Testament describes several cases of auto-transplantation by today's definition; Jesus of Nazareth reattached the ear of a servant after it had been cut by Simon Peter's sword. It also describes how Saint Mark re-implanted an amputated hand of a soldier ${ }^{[3]}$. Archaeological records have revealed that in the Bronze age, the term "trephination" was first revealed whereby bone segments were temporarily removed to decompress brain swelling ${ }^{[4]}$.

Jacopoda Varagine (348 AD) described the "miracle of the black leg" where a gangrenous leg of Justinian (Roman deacon) was replaced with that of a dead Ethiopian $\operatorname{man}^{[5]}$.

In 1688, Job van Meeneren successfully grafted a segment of bone from the skull of a dog to a defect in a human patient's cranium ${ }^{[6]}$. A Russian aristocrat had a fragment of canine skull tissue inserted during a repair after an injury. He had it explanted due to threats of excommunication from the church ${ }^{[6]}$. Such accounts of events highlighted the initial inquisitiveness with the concept of transplantation.

\section{THE PRE-TRANSPLANT ERA}

Although organ transplantation had not taken place yet, the early 20th century witnessed the first skin and corneal transplants. The initial work behind corneal transplant is attributed to Franz Reisinger who experimented with "keratoplasty" in $1818^{[7]}$. Twenty years later, Samuel Bigger performed the first successful corneal transplant in a gazelle. The first attempted corneal xenotransplantation on a human was performed in 1838 was unsuccessful. Improvements in antisepsis, anaesthesiology and surgical technique played a pivotal role, alongside ongoing animal experimentation. This subsequently led to the first successful human corneal transplant in 1905 by a Eduard Zirm (1887-1948) in Olmutz near Prague ${ }^{[7]}$. The first successfully grafted tissue however was performed by Jacques-Louis Reverdin, who transplanted small detached skin grafts onto a wound and noted hastened granulating of wounds on 8 th December $1869^{[8]}$. Solid organ transplantation would follow a similar path with years of experimentation, before successful results were noted.

French president Marie François Sadi Carnot died from severed portal vein in 1894. This had a profound effect on a young surgeon, Alexis Carrell ${ }^{[\rho]}$. He mastered vascular anastomotic suturing methods and introduced smaller needles. Carrel coated his needles, instruments and thread with petroleum jelly to reduce the thrombogenicity of the foreign material. He also perfected the concept of eversion thereby allowing blood within the vessels continuous endothelial contact. He also revolutionised antisepsis in surgery and pioneered methods of extracorporeal tissue preservation, by using salt solution at freezing point ${ }^{[10]}$.

In 1902, he successfully performed the first heterotopic kidney transplant by inserting a dog's kidney into its own neck. He noted that the kidney began producing urine immediately ${ }^{[9]}$. He later successfully transplanted organs, including kidneys, ovaries and thyroid glands between different dogs. In 1912, he became the first surgeon to win a Nobel Prize "in recognition of his work on vascular sutures and the transplantation of blood vessels and organs" ${ }^{,[11]}$.

To prevent blood clotting Carrel coated his needles, instruments and thread with paraffin jelly and he used an everting technique, rolling back the cut vessel ends like cuffs and then stitching the turned-back ends 
together to ensure that the blood would keep contact with the smooth inside of the vessel (endothelium). This and the use of strict asepsis to avoid infection allowed him to develop the techniques further by moving hearts, kidneys and spleens during experiments in dogs and also allowed other groups to begin experimentation in animal models of transplantation. Carrell famously noted that despite success in the technical aspects of transplantation, there were consistent hostile host responses to the foreign allografts especially during xenotransplantation ${ }^{[12]}$.

"Should an organ, extirpated from an animal and replanted into its owner by a certain technique, continue to functionate normally, and should it cease to functionate normally when transplanted into another animal by the same technique, the physiologic disturbance could not be considered as brought about by the organ but would be due to the influence of the host, that is, the biological factors".

Despite Carrell's observations, between 1905-1910, several surgical peers such as M Princeteau, Mathieu Jaboulay and Ernst Unger in this era attempted xenotransplantation of rabbit, pig and macaque kidneys to humans with disastrous results ${ }^{[13]}$.

\section{PRE-IMMUNOSUPPRESSION ERA}

Leo Loeb first noted that the strength and timing of rejection in skin homografts on rodents was potentially caused by genetic disparity between donor and recipient and highlighted the involvement of lymphocytes in the $1930 \mathrm{~s}^{[14]}$. He theorised that this genetic disparity did not occur in identical twins thus they would accept exchanged skin grafts. Unfortunately, his findings were ridiculed due to his inbreeding of mice. Contemporaries such as Peter Medawar dismissed the importance of lymphocytes and adopted the humoral theory of rejection ${ }^{[14]}$. The ensuing two decades were fraught with failed attempts of kidney transplantation in both human and animal models by Voronoy (1937), Simonsen (1953) and Dempster (1953) who even used radiation in organ transplant recipients ${ }^{[15]}$. Medawar's renewed interest in transplant rejection brought him to the Burns Unit at Glasgow Royal Infirmary (Gibson and Medawar, 1943) with Thomas Gibson. He remained convinced that skin grafts in burn victims failed because of humoral rather than cellular immunity ${ }^{[16]}$. His work with Rupert Billingham and Hugh Donald revealed that even fraternal twin cows accepted skin grafts, not just identical twin cows ${ }^{[17]}$. Across the Atlantic, Ray Owen at the University of Wisconsin noted a hybrid of blood cell types in fraternal twins. He concluded that there was persistence of chimerism from the intrauterine transfer of stem cells which was probably responsible for this ${ }^{[14]}$. Medawar, Billingham and Leslie Brent induced chimerism and homograft acceptance in mice by injecting inoculating intrauterine fetuses with donor strain spleen cell ${ }^{[1]}$. This was ultimately successful and resulted in a Nobel Prize in 1966 for Peter Medawar. They later discovered that some of the immunocompetent cells from the splenic tissues "attacked" the lymphoid tissue of the host (Graft-Versus-Host-Disease), thereby proving the role of cellular immunity as first theorised by Loeb ${ }^{[14]}$.

Meanwhile, Joseph Murray and his team performing the first successful kidney transplant in 1954 using as a donor the recipient's identical twin bypassing the issues with immunity ${ }^{[19]}$. This generated a lot of interest in the field of transplantation. Joan Main and Richmond Prehn attempted to recreate Medawar's stem cell inoculation. They radiated mice to allow induction of bone marrow from a donor. Murray's team used this method with poor outcomes as 11 of the 12 patients who underwent kidney transplantation with total body irradiation died within a month ${ }^{[14]}$. The survivor maintained adequate function of his fraternal twin's kidney for 20 years thereby becoming the first successful non-identical twin kidney transplantation. Jean Hamburger and René Küss from Paris performed 4 successful transplants using total body irradiation without marrow inoculation ${ }^{[15]}$. 


\section{EARLY IMMUNOSUPPRESSION}

Robert Schwartz and William Dameshek discovered that 6-mercaptopurine (6-MP), which was primarily used for treatment of malignancies, also reduced the antibody response of rabbits to bovine albumin ${ }^{[14]}$. Roy Calne used 6-MP on canine kidney homografts and noted that it significantly prolonged survival ${ }^{[20]}$. His findings however were not replicated when 3 kidney transplant recipients treated with 6-MP died. Calne began a research fellowship with Joseph Murray and despite the trend of total body irradiation, pursued work with 6-MP and later azathioprine ${ }^{[14]}$.

In 1963, at a National Research Council conference in Washington, the preliminary results of total body irradiation versus immunosuppressive drugs had reached equipoise with few patients surviving beyond 1 year. The practice of transplantation was questioned due to its poor long-term survival. Every represented centre demonstrated poor survival bar one. Thomas Starzl, combining azathioprine with prednisone achieved $>70 \%$ survival at 1-year follow up ${ }^{[21]}$. He noted that large doses of prednisone could reverse early rejection that occurred and this could then be tapered down. This led to the formation of 50 new transplant centres in the United States alone that year ${ }^{[16]}$ and remained the mainstay of immunosuppression for the next 20 years. Immunosuppression also brought a new pathology, opportunistic infections and malignancy. Starzl himself noted that there were a high rate of bacterial, viral, fungal and protozoal infections found in post-mortem examination ${ }^{[22]}$.

Antilymphocyte serum (ALS) was first discovered by Elie Metchnikoff in 1899. In 1961, Byron Waksman identified that lymphocytic depletion could suppressed delayed hypersensitivity reactions ${ }^{[23]}$. Combining the two concepts, Michael Woodruff demonstrated that ALS administration alongside thoracic duct drainage via a fistula extended skin allograft survival in rodents, a finding later replicated by Medawar ${ }^{[24,25]}$. In 1966, Polyclonal antilymphocyte globulin (ALG) was successfully synthesized from human leukocyte inoculated horses and became the staple of a triple regimen alongside steroids and azathioprine ${ }^{[26]}$.

\section{HISTORY OF CARDIAC SURGERY AND TRANSPLANTATION}

Unlike its other surgical counterparts, cardiac surgery was a relatively unknown subspecialty in the early 20th century. In 1881 at the Vienna Medical Society, Theodore Billroth once proclaimed.

"No surgeon who wished to preserve the respect of his colleagues would ever attempt to suture a wound of the heart" ${ }^{\text {"27] }}$.

The first cardiac procedure of the modern era was performed by Henry C. Dalton in St. Louis to repair a pericardial wound in a victim of a stabbing ${ }^{[28]}$. In 1923, Elliot Carr Cutler and Samuel A. Levine successfully relieved a stenotic mitral valve in a 12 -year-old girl. F. John Lewis, performed the first successful repair of an atrial septal defect in 1952 using hypothermia to protect the myocardium ${ }^{[2]}$. C. Walton Lillehei performed 45 open heart surgeries utilizing a technique called controlled cross-circulation using parents of the children as "pump oxygenators" ${ }^{\text {"[30] }}$.

The introduction of the cardiopulmonary bypass circuit revolutionised cardiac surgery. John Gibbon perfected the device in 1953 and subsequently perfored the successfully performed an atrial septal defect closure $^{[31]}$. John Kirklin modified the pump and achieved relative success in small series of patients at the Mayo Clinic $^{[32]}$. However it was Richard DeWall's cardiopulmonary bypass device with a disposable bubble oxygenator and simple pump action that enabled the correction of cardiac conditions under direct vision ${ }^{[33]}$.

The ensuing period saw numerous attempts to correct myocardial ischaemia until the Robert Hans Goetz successful grafted the right internal mammary artery to the right coronary artery, thereby performing the first coronary artery bypass graft in 1960 , much to the chagrin of the medical and surgical fraternity at the time ${ }^{[34]}$. 
Inspired by the work of Carrel and Loeb, Frank C Mann identified 2 techniques for heterotopic cardiac transplantation ${ }^{[35]}$. In his experimental model, he described using either a distal or proximal end of a divided carotid artery to supply blood to the aorta and assist circulation. The coronary sinus blood returned to the right atrium with both the vena cavae closed off and drained into the right ventricle. The pulmonary artery was anastomosed to the jugular vein. They noted that the pulse generated by the heart gradually faded with the longest lasting heart failing after 8 days.

Vladimir Demikhov, a visionary surgeon developed a mechanical device too large to be inserted entirely within the thorax of a dog, but it functioned as a substitute for the heart for as long as $5.5 \mathrm{~h}$. Till 1946, intrathoracic transplantation had never been accomplished in a warm-blooded animal. The first issue encountered was ongoing nourishment of the heart using arterialised blood. He ligated of the aorta, venae cavae, azygos, and brachiocephalic and left subclavian arteries perfused the heart with arterialised blood was returned to the left atrium after passing through the pulmonary circuit and delivered by the left ventricle into the coronaries. He used this method in around 300 experiments and maintained the heart in good condition for up to $4 \mathrm{~h}^{[36]}$.

Despite multiple initial failures of intrathoracic transplant of the heart, one dog survived for 32 postoperative days. Perhaps his greatest achievement was a series of orthotopic heart transplants that he performed without hypothermia or the use of a cardiopulmonary bypass machine. He performed and end-to-side anastomosis of the donor aorta, pulmonary artery and venae cavae to the corresponding recipient vessels and reattached the pulmonary veins to the recipients left atrium and closed off with a purse strings. He reported survival times of up to $15.5 \mathrm{~h}$, thereby creating the first model of an orthotopic heart transplant providing the entirety of the pumping function ${ }^{[37]}$. Demikhov's research was not published in English until 1962.

Interest in Frank C Mann's work was rekindled in 1951. Marcus et al created a technique using 3 dogs, a donor, a recipient and a receptacle for the donor heart when disconnected from the circulation ${ }^{[38]}$. The final model was not to dissimilar to the cross-circulation utilized by Lillihei. This "interim parabiotic perfusion" was used to place the heart in the 2 previously mentioned configurations as described by Mann. In 1953, Marcus and associates managed to achieve a survival time of $48 \mathrm{~h}$ for heterotopic heart transplantation ${ }^{[39]}$. Wilfred Neptune and colleagues were the first to utilise hypothermia with a heart-lung block and achieved a survival time of $6 \mathrm{~h}$ in a canine model ${ }^{[40]}$.

Webb, Howard and Neely produced 12 successful orthotopic heart transplants surviving as long as $7.5 \mathrm{~h}$ using a different method of anastomosing the pulmonary veins of the donor to recipient compared to Demikhov $^{[41]}$. The first involvement of British cardiac surgeons occurred in 1959 when Cass and Brock described a series of methods for autotransplantation while including leaving the recipients atria and septal crest behind to avoid pulmonary vein and vena cavae anastomosis ${ }^{[42]}$.

In 1960, Lower and Shumway published results of their experiments with orthotopic homotransplantations using an oxygenator and partial atrial preservation as described by Cass and Brock. They yielded excellent results with 5 of the 8 dogs experimented on surviving between $6-21$ days ${ }^{[43]}$. To date, the bi-atrial anastomosis is still noted as the Shumway Technique.

Shumway paid meticulous attention to surgical technique and myocardial protection using isotonic saline at $4{ }^{\circ} \mathrm{C}$. In addition they introduced the concept of assistance time whereby the recipient dogs were left on the cardiopulmonary bypass for a short period of time to ease the heart into assuming the circulatory load ${ }^{[44]}$.

Shumway's group also described initial issues such as the incidence of complete atrioventricular block. On learning lessons from rejection in renal transplant patients, Reemtsa et al attempted to use methotrexate 
for heterotopic heart transplantation in 21 canines, and prolonged survival up to 26 post-operative days ${ }^{[45]}$. Blumenstock mimicked the findings of Reemtsma's group with one canine in their cohort surviving for up to 42 days in $1963^{[46]}$.

The first ethical dilemma faced by the fraternity was the concept of the donor as "the definition of irreversible coma" was only established in 1968 by an Ad Hoc Committee of Harvard Medical School on Brain Death $^{[47]}$. The likelihood of a potential donor dying at exactly the same time as a recipient needing a heart was minute and a decision was made that the team would not halt ventilation of the patient in January 1964, but instead would utilise a chimpanzee as a donor ${ }^{[48]}$. A patient presented with a large thrombus that had embolised to the left side of the heart and placed on mechanical coronary perfusion. The chimpanzee heart was explanted and implanted into the patient. Despite initially beating well, it became apparent that the heart was not able to support the larger volume of a human circulation and the patient died within an hour of weaning from cardiopulmonary bypass.

Dr. Christiaan Barnard had worked alongside Shumway in Minnesota. He had also performed the first successful kidney transplant in South Africa to understand transplant immunology and geared for a heart transplantation. On 14th September 1967, Louis Washkansky was admitted in the Groote Schuur Hospital in Cape Town, South Africa. Dr. Velva Schrire (Chief Cardiologist) recommended Washkansky as the appropriate case for transplant. On 2nd December 1967, a 24-year-old female, Denise Ann Darvall was pronounced dead after sustaining a massive cerebral injury following a collision. Both patients were brought to theaters $\mathrm{A}$ and $\mathrm{B}$ where and mutual consent was obtained ${ }^{[49]}$.

"If you can’t save my daughter, you must try and save this man." Edward Darvall (Denise's Father).

On 3rd December 1967, Dr. Christiaaan Barnard performed the first successful human-to-human orthotopic heart transplantation. Her heart was taken via the Shumway technique with the heart cooled to $10^{\circ} \mathrm{C}$. He used a combination of local irradiation, azathioprine, prednisone, and actinomycin $\mathrm{C}$ as his immunosuppression regime. The post-operative course of the patient was very promising, he contracted Pseudomonas pneumonia and died on the 18 th post-operative day ${ }^{[50]}$.

Dr. Adrian Kantrowitz and his team performed the 2nd heart transplant (the first in a paediatric patient) in Brooklyn. Kantrowitz was already well known for designing the first intra-aortic balloon pump and had conducted considerable laboratory experiments in puppy hearts believing that the immune system of a younger heart may offer less allogenic resistance. On 6th December 1967, He transplanted a anencephalic donor heart into a 3 week-old patient diagnosed with tricuspid atresia. He performed the operation in hypothermic conditions under circulatory arrest. Despite initial recovery into sinus rhythm, the recipient developed irreversible acidosis and $\operatorname{died}^{[51]}$.

Norman Shumway and his team performed their first heart transplant a month after Kantrowitz. The recipient developed chronic and progressive heart failure after "post-viral myocardial fibrosis" and coronary artery disease. The procedure was complicated by size mismatch with the donor heart being much smaller than the recipient's. The recipient received a combination of methylprednisolone and azathioprine preoperatively and post-operatively with the addition of prednisolone. However, the patient did not succumb to rejection. Shumway noted that in the initial post-operative period the patient was mildly hypotensive and oliguric into the second postoperative day despite administration of isoproterenol and temporary digitalization. The patient developed a consumptive coagulopathy before succumbing to multiorgan dysfunction and bronchopneumonia ${ }^{[52]}$.

Across the Atlantic, Dr. Donald Ross, who trained under Lord Russell Brock, performed the first heart transplant in the United Kingdom. The patient, a 45 -year-old man, survived for 46 days before succumbing 
to infection. He performed 2 more unsuccessful transplants before a moratorium was declared ${ }^{[53]}$.

Denton Cooley's group reported moderate success early on at Baylor with 7 of 10 patients surviving 4.5 months ${ }^{[54]}$. To reduce the risk of rejection, they used blood-group compatibility, lymphocyte crossmatch studies (histocompatibility) as described by Dr. Paul Terasaki, and developed a matching system to predict the likelihood of a good outcome post-transplant ${ }^{[55]}$. They also administered anti-lymphocyte globulin in addition to the other anti-rejection medications.

\section{EARLY ISSUES WITH HEART TRANSPLANTATION}

Within a year of the Barnard's feat, 102 heart transplantations were performed internationally ${ }^{[56]}$. Shumway famously quipped "Suddenly heart transplants were being done in places where one would hesitate to have his atrial septal defect closed".

The early promise of heart transplantation however soon diminished asthe number of transplants rapidly fell from 100 (1968) to 18 (1970), with many inexperienced units abandoning the procedure. Kantrowitz, who was on the review panel for the National Institute of Health agreed to support Shumway and his unit in their ongoing research ${ }^{[57]}$. In 1971, they identified several identifiers of acute rejection ${ }^{[58]}$ :

(1) Electrocardiographic findings: i. Increased QRS voltage; ii. Arrhythmia; iii. Right axis deviation; iv. ST-T wave changes;

(2) Clinical Findings: i. Appearance of gallop rhythm; ii. Decreased precordial activity; iii. Hypotension;

(3) Echocardiography findings: i. Increased thickness of left ventricular wall; ii. Increased right ventricular diameter.

Using the above-mentioned criteria, they successfully treated 57 of 60 patients with methylprednisolone, actinomycin D and ALG. As the experience of long-term survival in heart transplants increased, Shumway noted a condition he titled "chronic rejection",[59]. It manifested as diffuse allograft vasculopathy and led to episodes of sick sinus syndrome or myocardial infarction, usually proving fatal.

In 1962, Dr. Souji Konno developed the catheter-type endomyocardial biopsy (EMB) allowing samples of myocardium of patients suspected of having intrinsic musculature abnormality to be taken using a bioptome inserted via a peripheral vein or arterial cutdown ${ }^{[60]}$. It was initially developed for diagnoses of cardiomyopathies as opposed to limited thoracotomy approaches. The biotome usually provided samples containing endocardium and myocardium, usually sufficient for microscopic examination.

In 1971, a young cardiothoracic surgeon, Dr. Philip Caves undertook a British American Research Fellowship to Stanford to work with Shumway. While here, he worked with instrument maker, Werner Schulz to create the Stanford-Caves Schulz bioptome which transformed the management of heart transplant patients. There were 2 Stanford bioptomes that differed in size and length. The longer and thinner bioptome was used for left ventricular biopsy and the shorter and thicker one for right ventricular biopsy ${ }^{[61,62]}$. The samples obtained were between 1-3 $\mathrm{mm}$ in diameter. He noted that changes seen in endomyocardial specimens matched those seen in grafts at post-mortem examinations. The samples taken from the endomyocardial surface were also free of post-operative inflammatory changes that complicated sub-epicardial samples taken during thoracotomy. Finally, he noted that the pathologic changes of cardiac allograft rejection were more prominent in the endomyocardial surface (as the graft came in direct contact with the host's circulation). Philip Caves also worked with Margaret Billingham who was a pathologist at Stanford. In 1974, they developed a standardised histological scale to pathologically grade the severity of cardiac rejection based on the extent of infiltrates ${ }^{[63]}$. This was incorporated into routine practice and significantly improved the survival of heart transplant recipients at Stanford. 


\section{IMMUNOSUPPRESSION IN HEART TRANSPLANTATION}

\section{Ciclosporin}

Another notable feat in transplantation during this era was the discovery of Ciclosporin A. In 1976, J.F Borel reported the immunosuppressive effects of a fungal metabolite (Tolypocladium inflatum) isolated from Swiss soil samples. He noted that skin graft rejection in mice and graft-versus-host disease in mice and rats were considerably delayed by cycloporin A. He also noted that it had a direct antilymphocytic effect by targeting an early stage of mitogenic triggering of the immunocompetent lymphoid cell and lacked the myelosuppressive effects of cytostatic drugs used at the time ${ }^{[64]}$. Roy Calne, who previously worked on azathioprine, conducted in vivo immunosuppression with ciclosporin A on porcine cardiac allografts. His group stated that "Ciclosporin A is more effective in suppressing rejection than any other drug that we have used in pigs with orthotopic cardiac allografts",

Terence English, a South African born surgeon who previously worked with Lord Russell Brock and Donald Ross, nearly abandoned medicine to be a mining engineer. He visited Stanford on advice of his friend Philip Caves in $1973^{[66]}$. He was truly impressed with the outcomes of heart transplant recipients at the unit. In 1978, Terence English, sought approval from the Transplant Advisory Panel of the Department of Health but was informed that there were no funds for a transplant programme ${ }^{[6]]}$. Given the moratorium, the panel were not keen on "one-off" operations. He duly persisted but his initial attempt was unsuccessful as the donor had arrested prior to implantation and sustained an irreversible brain injury. He persevered and in July 1979, performed the first successful heart transplant in the United Kingdom. The recipient, Keith Castle lived for 5 and a half years ${ }^{[68]}$.

"He subsequently became the best possible advertisement for cardiac transplantation except for his inability to give up smoking" Sir Terence English on Keith Castle ${ }^{[68]}$.

Although initial reports on Ciclosporin were favourable, the improvements came with a price. Ciclosporin was nephrotoxic when used over a long period ${ }^{[69]}$. Other side effects include hypertension, hepatotoxicity, gingival hyperplasia, hypertrichosis, involuntary tremor, and an increased risk of malignancy ${ }^{[70]}$. With the improvements in survival after the initial transplantation, the recipients were at risk of nephrotoxicity and morbidities associated with immunosuppression primarily infections. These drawbacks however did not offset positive impact Ciclosporin offered over previous methods. Immunosuppression formed the initial challenges in cardiac transplantation with suboptimal immunosuppressive regimens either causing allograft rejection or infectious complications from over-immunosuppression.

A European Multicentre trial evaluating renal graft survival at 1-year showed that Ciclosporin alone as a first-line immunosuppressive agent was more effective than with azathioprine and steroids ${ }^{[71]}$. Stanford's group meanwhile reported 1 and 5 -year survival rates of $83 \%$ and 55\%, respectively using a 3 -drug protocol of Ciclosporin A, azathioprine, and prednisone ${ }^{[72]}$.

\section{Tacrolimus}

Tacrolimus (Tradename: Prograf ${ }^{\oplus}$, Astellas Pharma US, Inc. Northbrook, IL) a calcineurin inhibitor like Ciclosporin was discovered from a soil sample from the foot of Mount Tsukuba in Tokyo in 1984. It was cultured from an actinobacter, Streptomyces tsukubaensis ${ }^{[73]}$. It suppresses interleukin-2 production associated with T-cell activation, thus inhibiting the differentiation and proliferation of cytotoxic $\mathrm{T}$ cells. Thomas Starzl once again led research into safety and efficacy of Tacrolimus at University of Pittsburgh Medical $\mathrm{School}^{[7]}$. Tacrolimus had a more limited adverse effect profile and comparative studies suggest superiority over Ciclosporin in preventing allograft rejection while causing less antibody suppression ${ }^{[75,76]}$. The pharmacokinetics were far more predictable than for micro-emulsion Ciclosporin ${ }^{[77]}$. 
Numerous randomized controlled trials comparing tacrolimus to Ciclosporin have been done. Two multicentre studies comparing tacrolimus to oil-based Ciclosporin (Tradename: Sandimmune ${ }^{\bullet}$ Oral Solution, Novartis Pharmaceuticals Corporation, East Hanover, New Jersey) showed no significant difference between the groups at 12 months. Graft survival, renal function and infection rates were not significantly different between the groups although more patients in the Ciclosporin group developed hypertension and hypercholesterolaemia ${ }^{[78,79]}$.

A micro-emulsion formulation of Ciclosporin (Tradename: Neoral ${ }^{\circledR}$ Oral Solution, Novartis Pharmaceuticals Corporation, East Hanover, New Jersey 07936) was developed and was shown to have a better bioavailability profile with more predictable pharmacokinetics compared to the oil-based preparations ${ }^{[80]}$. A multicenter, randomized study of both preparations of Ciclosporin revealed fewer episodes of rejection requiring antilymphocyte antibodies and fewer study discontinuations for treatment failures in the micro-emulsion based Ciclosporin cohort of patients compared to those treated with oil-based Ciclosporin without any adverse events ${ }^{[81]}$.

When compared to tacrolimus, micro-emulsion based Ciclosporin (alongside cytolytic induction) and a tapered steroid regime showed equivalent patient and graft survival at 19 months. However, there was an increased incidence of biopsy proven acute rejection in the Ciclosporin group at 6 months. Tacrolimus was associated with a higher incidence of new-onset diabetes mellitus, lower rates of post-transplant hypertension and lower incidences of dyslipidaemia ${ }^{[82]}$. Similar findings were noted in another trial without cytolytic induction ${ }^{[83]}$.

\section{Mycophenolate mofetil}

Another agent that is commonly used is [mycophenolate mofetil (MMF); CellCept, Roche Laboratories, Nutley, NJ]. It is an effective anti-proliferative agent that improves rejection and survival when used as part of combination therapy. Its active metabolite, mycophenolic acid, is a non-competitive inhibitor of inosine monophosphate dehydrogenase in the de novo pathway for purine synthesis ${ }^{[8]}$. Therefore, MMF has some selectivity for lymphocytes over other cell types as lymphocytes rely on this pathway for DNA replication and proliferation. Studies have shown that heart transplant patients receiving MMF therapy had lower levels of C-reactive protein, circulating B lymphocytes, activated T lymphocytes and natural killer (NK) cells compared to patients receiving azathioprine ${ }^{[85]}$.

\section{Mechanistic target of rapamycin inhibitors}

Everolimus (Tradename: Certican, Novartis Pharma Schweiz AG, Bern, Switzerland) and Sirolimus (Tradename: Rapamune, Wyeth Europa Ltd., Maidenhead, UK) are mechanistic target of rapamycin inhibitors ${ }^{[8]}$. They work by inhibiting proliferation signals by suppressing the cytokine-driven T-lymphocyte proliferation, resulting in an arrest of the cell cycle. Unlike the calcineurin inhibitors, they demonstrate little or no nephrotoxic side effects. Recent studies have even shown a reduction in the incidence of chronic allograft vasculopathy(CAV) with Everolimus as measured by IVUS among heart-transplant recipients after 1 year ${ }^{[87,88]}$. Sirolimus however is linked to an increase in total cholesterol and triglyceride levels ${ }^{[89,90]}$. Everolimus on the other hand, is linked with an increase in total cholesterol levels, without increased triglyceride levels, but a significant increase in HDL which may explain its attenuation of $\mathrm{CAV}^{[91]}$.

\section{Cytolytic induction therapy}

Cytolytic Induction therapy comprises of immunosuppressive drugs that have been introduced into clinical transplantation directed against human lymphoid cells. Several different forms of cytolytic induction therapy have been used as identified in Table 1.

In heart transplantation especially, kidney dysfunction has been demonstrated to be risk factors for early death $^{[93,94]}$. Cytolytic induction allows post-operative renal recovery from a pre-renal aetiology without the 
Table 1. Different types of cytolytic induction therapy available (adapted with permission from Wahlers ${ }^{[92]}$ )

\begin{tabular}{|c|c|c|c|c|}
\hline Substance & Origin & Dosages applied & Routes investigated & Monoclonal/polyclonal \\
\hline Antilymphocyte-Globulin ATGAM & Horse & Various 7-14 days & IM & Polyclonal \\
\hline Antithymocyte-Globulin Bieber-ATG Tecelac & Rabbit & $\begin{array}{l}1,5-3 \mathrm{mg} / \mathrm{kg} \text { per day } \\
1-10 \text { days }\end{array}$ & IM/IV & Polyclonal \\
\hline OKT III antibody & Mouse & $\begin{array}{l}\text { 5-10 mg/day } \\
\text { 4-14 days }\end{array}$ & IV & Monoclonal \\
\hline BMA 031 antibody & Mouse & Experimental & IV & Monoclonal \\
\hline Anti-LFA antibody & Synthetic & Experimental & IV & Monoclonal \\
\hline
\end{tabular}

negative impact of high nephrotoxic ciclosporinCiclosporin/tacrolimus levels. It effectively allows bridging of immunosuppression until a steady state is reached for the regular immunosuppression medications. Most centres use a combination of the abovementioned immunosuppressants to achieve adequate immunosuppression. In 2006, Kobashigawa led a trial comparing 3 different immunosuppression regimes, micro-emulsion Ciclosporin with MMF, tacrolimus with MMF or tacrolimus with sirolimus ${ }^{[95]}$.

The 343 heart transplant recipients in this trial were randomized to receive corticosteroids and on of the mentioned regimes. Cytolytic induction therapy was used for up to 5 days. The primary endpoint of moderate rejection or haemodynamic compromise rejection requiring treatment showed no significant difference between the three groups at 6 months and 1 year. The probability of treated rejection was significantly lower in both the tacrolimus groups compared with the micro-emulsion Ciclosporin/mycophenolate mofetil group. The tacrolimus/sirolimus group had more fungal infections and more impaired wound healing.

On the other hand, recent trials involving combinations with everolimus have shown promising results including reduced cytomegalovirus infections ${ }^{[96]}$, reduced cutaneous cancer incidence ${ }^{[97]}$, and CAV attenuation effects ${ }^{[98]}$.

\section{CURRENT STATUS OF HEART TRANSPLANTATION}

Heart transplantation is considered to be the "gold-standard treatment" for refractory advanced heart failure in carefully selected patients ${ }^{[99-101]}$. A major limiting factor of transplantation is the emerging gap between the number of donors (available grafts) and the number of patients on the waiting list. This issue is apparent even in the neighbouring France ${ }^{[102]}$. The utilization of marginal donors or expanded-criteria donors has steadily increased over the decades. Part of the decision-making process currently between physician, surgeon and patient includes discussing the potential options available. Currently, the choices include continued medical therapy ( $5 \%$ to $10 \%$ weekly mortality risk), mechanical circulatory support (10\% to $15 \%$ operative risk), or a transplant which may or may not include a clause for marginal organs.

The "Standard Donor" or "Traditional Criteria" for a donor as suggested by Copeland ${ }^{[103]}$ is as follows: (1) age < 50 years; (2) echocardiogram showing no important segmental abnormalities or global hypokinesis, ejection fraction greater than 50\%, and normal valves; (3) inotropes less than $15 \mu \mathrm{g} / \mathrm{kg} / \mathrm{min}$ of dopamine; (4) donor to recipient weight ratio 1.5 to 0.7 ; (5) cold ischemic time less than $4 \mathrm{~h}$; (6) no donor infection; (7) negative serology for hepatitis B, hepatitis C, and human immunodeficiency Virus; and (8) normal electrocardiogram or minor ST-T wave abnormalities, with no conduction system disease.

The rising number of patients listed for heart transplantation has resulted in an increased number of donors from beyond the "standard criteria" pool as a result of the undersupply of available organs. "Marginal Donors" as they are termed would, under conventional transplant guidelines, be declined as potential organ donors ${ }^{[104]}$. Median waiting times in the UK for hearts on the non-urgent list is currently 1280 days and 26 days for the urgently listed ${ }^{[105]}$ [Figure 1]. 


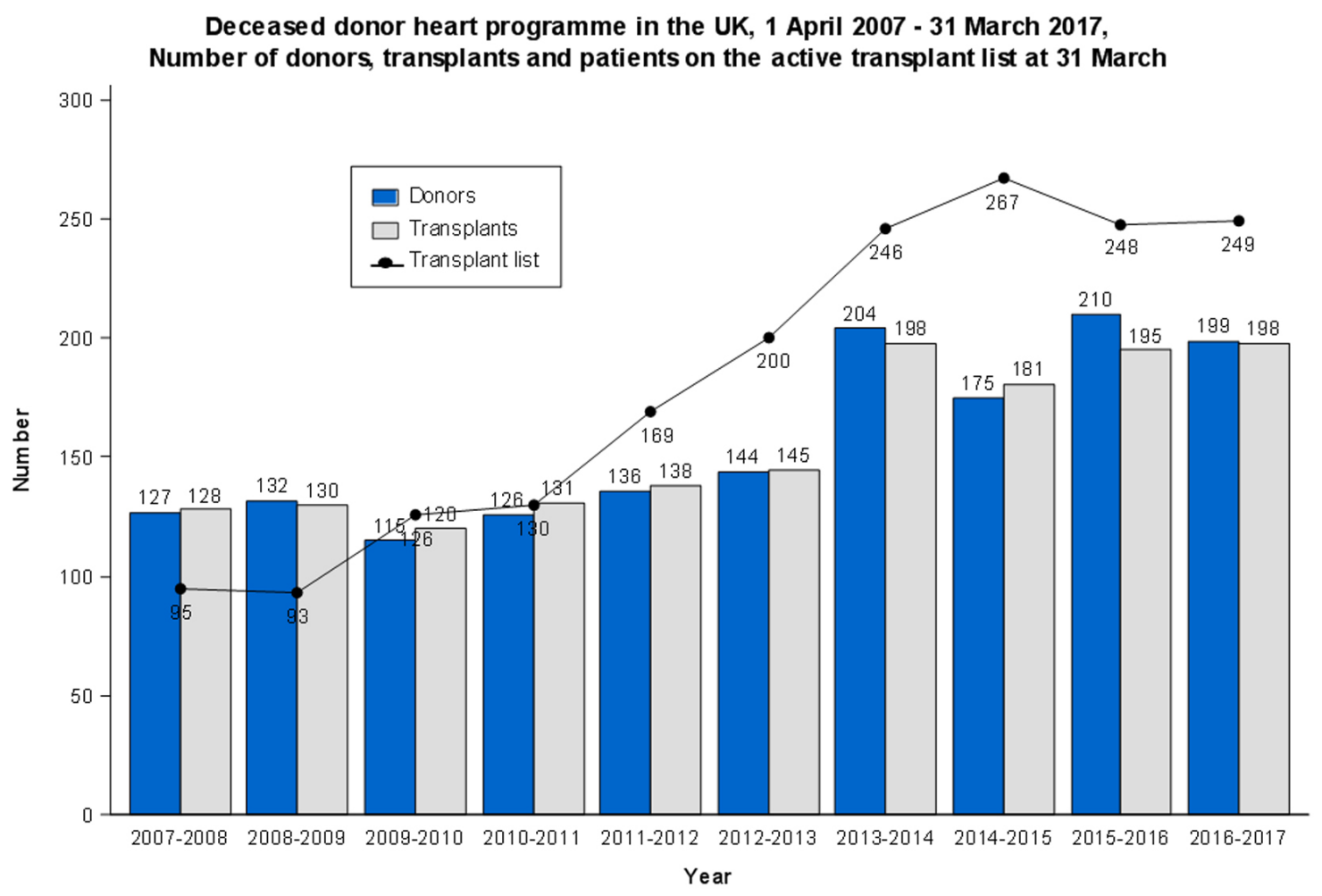

Source: Transplant activity in the UK, 2016-2017, NHS Blood and Transplant

Figure 1. Deceased donor heart programme in the UK, 1 April 2007 - 31 March 2017, number of donors, transplants and patients on the active transplant list at 31 March

Forays into xenotransplantation as a potential pool of organs to solve the problem of donor-organ supply were also touted but to date, these remain in the experimental phase ${ }^{[106]}$.

The decision to accept a marginal donor organ is made on a recipient focused individualized basis rather than specific values, parameters or conditions [Figure 2].

The number of "standard donors" for kidney transplants were first notably reduced after the implementation of the compulsory wearing of seat belts in the United Kingdom which was approved by parliament in 1982 and became law on 1 February $1983^{[107]}$. Other legislations include zero-tolerance drinking-anddriving law resulting in fewer traffic accidents with fatal victims ${ }^{[108]}$. During this time period the United Kingdom Transplant Support Service Authority demonstrated a 12\% increase in the number of cardiac donors aged greater than 41 years between 1988 and $1995^{[109]}$. The initial reluctance to use organs from older donors especially the heart was due to longstanding dogma that older hearts were thought to more susceptible to the catecholamine flood that accompanies brain death ${ }^{[110]}$. Internationally, gun crime has also been closely associated with donor organ availability. Studies in Brazil have shown a direct correlation between urban violence and gun crime to organ donors ${ }^{[11,112]}$.

Initial studies exploring the extended age criteria showed no significant difference in terms of left ventricular function and the incidence of infection and rejection ${ }^{[109,113]}$. The risk of dying on the waiting list outweighed that of receiving an organ from an older donor ${ }^{[114]}$. 
1985

- Initial success of heart transplantations

- 'Standard' criteria donors reduced due to seat-belt law in UK
1995

- Mild

atrioventricular

valve insufficiency

acceptable for

transplant

- Size mismatch

- Ischaemic times
2005

- Donors after circulatory death (Paediatrics)

- Hepatitis B/C donors

- Brain malignancies
2015

- Successful use of marginal hearts on the Organ Care System

- First adult DCD heart transplant done in Australia

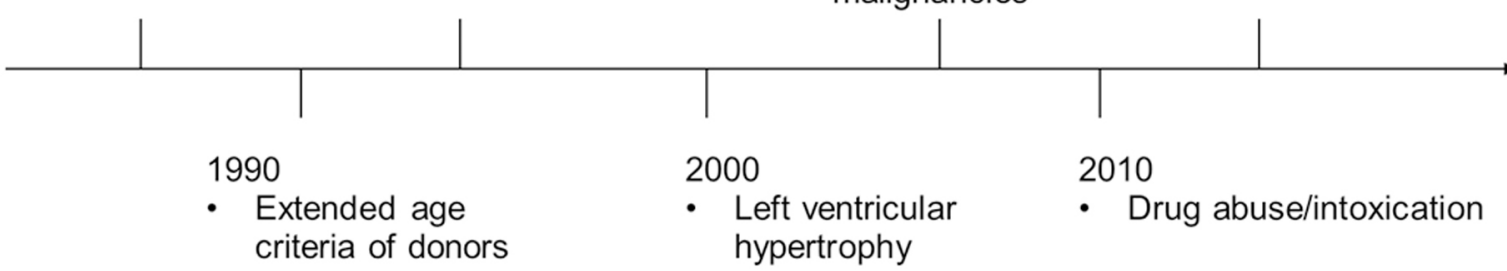

Figure 2. Timeline of events where modifications of "Standard criteria" toward more marginal donors were implemented

Some surgeons also opted to accept hearts with mild-to-moderate mitral or tricuspid insufficiency or secundum-type atrial septal defects as these could be repaired immediately or post-operatively with good results ${ }^{[15]}$.

As the understanding of myocardial protection improved, the use of mildly hypertrophic left ventricles with short ischaemic times were also proposed with the caveat that there were no ECG changes ${ }^{[116]}$.

Patients with underlying malignancies were previously never considered donor candidates. However, the risk of metastasis from a primary intracranial tumour is low. A German study in one of the earliest studies evaluating the outcomes of recipients receiving organs from donors with intracranial malignancies showed good follow up outcomes of more than 5 years ${ }^{[17]}$.

Transplantation also requires commitment from the patients and health care providers as it involves a long-term programme of treatment including pharmacological immunosuppression and regular surveillance ${ }^{[118]}$. Clinical decisions therefore should consider a patient's ability to adhere to the demands of ongoing treatment. Alternatives to transplantation include the use of Ventricular Assist Devices (VADs). These are however limited in the National Health Service (NHS) due to the limited health care funding. In North America, the Food and Drug Administration recently approved VADs as destination therapy ${ }^{[119]}$. In its current form, heart transplantation confers a significant survival advantage with a 1-year survival of $84.5 \%$ and a 5 -year survival of $72.5 \%$ which is significantly improved as compared to the $76.9 \% 1$-year survival and $62.7 \%$-year survival in the $1980 \mathrm{~s}^{[120,121]}$.

\section{PRIMARY DIAGNOSTIC INDICATIONS FOR TRANSPLANT}

The most frequent indications for heart transplantation in adults are chronic heart failure secondary to dilated cardiomyopathy or ischaemic heart disease ${ }^{[118]}$. There is also a significant number of patients(approximately 3\%) with adult congenital heart disease who present with advanced heart failure in adulthood ${ }^{[122]}$. These patients are slightly more complex to manage both surgically (due to the abnormal anatomy, complex adhesions) and medically (due to human leucocyte antigen sensitisation, potentially elevated pulmonary vascular resistance secondary to univentricular circulations and erythrocytosis secondary to cyanosis $)^{[118,122]}$. Coronary artery disease is the most important contributor to heart failure with a population-attributable risk of $65 \%$ in men and $48 \%$ in women ${ }^{[123]}$. Most of the patients however can be classified into ischaemic or non-ischaemic cardiomyopathies. 


\section{DECLARATIONS}

\section{Authors' contributions}

Wrote, drafted, and edited the manuscript: Singh SSA

Supervised: Banner N

Reviewed and edited the manuscript: Berry C, Al-Attar N

\section{Availability of data and materials}

Not applicable.

\section{Financial support and sponsorship}

None.

\section{Conflicts of interest}

All authors declared that there are no conflicts of interest.

\section{Ethical approval and consent to participate}

Not applicable.

\section{Consent for publication}

Not applicable.

\section{Copyright}

(c) The Author(s) 2018.

\section{REFERENCES}

1. Bergan A. Ancient myth, modern reality: a brief history of transplantation. J Biocommun 1997;24:2-9.

2. Salguero CP. Buddhism \& Medicine in East Asian history. Religion Compass 2014;8:239-50.

3. Linden PK. History of solid organ transplantation and organ donation. Crit Care Clin 2009;25:165-84.

4. Goodrich JT. The ancient art of trepanation--a Greek Bronze Age "hole in the skull". World Neurosurg 2014;81:296-7.

5. Gutkind L. Many sleepless nights: the world of organ transplantation. Norton \& Company; 1988.

6. Hewitt CW, Gordon CR, Lee WPA. Transplantation of composite tissue allografts. New York: Springer; 2008.

7. Crawford AZ, Patel DV, McGhee CNJ. A brief history of corneal transplantation: from ancient to modern. Oman J Ophthalmol 2013;6:S12-7.

8. Davis JS. Address of the president: the story of plastic surgery. Ann Surg 1941;113:641-56.

9. Merchant J, Tan SY. Alexis Carrel (1873-1944): pioneer of vascular surgery and organ transplantation. Singapore Med J 2013;54:602-3.

10. Aida L. Alexis Carrel (1873-1944): visionary vascular surgeon and pioneer in organ transplantation. J Med Biogr 2014;22:172-5.

11. Sade RM. Transplantation at 100 years: Alexis Carrel, pioneer surgeon. Ann Thorac Surg 2005;80:2415-8.

12. Shayan H. Organ transplantation: from myth to reality. J Invest Surg 2001;14:135-8.

13. Cooper DKC, Kemp E, Platt JL, White DJG. Xenotransplantation. Berlin: Springer; 1997.

14. Barker CF, Markmann JF. Historical overview of transplantation. Cold Spring Harb Perspect Med 2013;3:a014977.

15. Dempster WJ. Kidney homotransplantation. Br J Surg 1953;40:447-65.

16. Brent LB. A history of transplantation immunology. Los Angeles Press; 2005.

17. Anderson D, Billingham RE, Lampkin GH, Medawar PB. The use of skin grafting to distinguish between monozygotic and dizygotic twins in cattle. Heredity 1951;5:379.

18. Billingham RE, Brent L, Medawar PB. Actively acquired tolerance of foreign cells. Nature 1953;172:603-6.

19. Harrison JH, Merrill JP, Murray JE. Renal homotransplantation in identical twins. Surg Forum 1956;6:432-6.

20. Calne RY. The rejection of renal homografts. Inhibition in dogs by 6-mercaptopurine. Lancet 1960;1:417-8.

21. Hamilton D, Barker CF, Starzl TE. A history of organ transplantation. Pittsburgh Press; 2012.

22. Hill RB Jr, Dahrling BE, II, Starzl TE, Rifkind D. Death after transplantation. Am J Med 1967;42:327-34.

23. Waksman BH, Arbouys S, Arnason BG. The use of specific "lymphocyte" antisera to inhibit hypersensitive reactions of the "delayed" type. J Exp Med 1961;114:997-1022.

24. Woodruff MF, Anderson NA. Effect of lymphocyte depletion by thoracic duct fistula and administration of antilymphocytic serum on 
the survival of skin homografts in rats. Nature 1963;200:702.

25. Levey RH, Medawar PB. Nature and mode of action of antilymphocytic antiserum. Proc Natl Acad Sci U S A 1966;56:1130-7.

26. Starzl TE, Marchioro TL, Porter KA, Iwasaki Y, Cerilli GJ. The use of heterologous antilymphoid agents in canine renal and liver homotransplantation and in human renal homotransplantation. Surg Gynecol Obstet 1967;124:301-8.

27. Weisse AB. Medical odysseys. New Jersey Press; 1991.

28. Weisse AB. Cardiac surgery: a century of progress. Tex Heart Inst J 2011;38:486-90.

29. Lewis FJ, Taufic M. Closure of atrial septal defects with the aid of hypothermia; experimental accomplishments and the report of one successful case. Surgery 1953;33:52-9.

30. Lillehei CW, Varco RL, Cohen M, Warden HE, Patton C, et al. The first open-heart repairs of ventricular septal defect, atrioventricular communis, and tetralogy of Fallot using extracorporeal circulation by cross-circulation: a 30-year follow-up. Ann Thorac Surg 1986;41:4-21.

31. Gibbon JH Jr. The development of the heart-lung apparatus. Am J Surg 1978;135:608-19.

32. Kirklin JW, Dushane JW, Patrick RT, Donald DE, Hetzel PS, et al. Intracardiac surgery with the aid of a mechanical pump-oxygenator system (gibbon type): report of eight cases. Proc Staff Meet Mayo Clin 1955;30:201-6.

33. Dewall RA, Gott VL, Lillehei CW, Read RC, Varco RL, et al. A simple, expendable, artificial oxygenator for open heart surgery. Surg Clin North Am 1956:1025-34.

34. Konstantinov IE. Robert H. Goetz: the surgeon who performed the first successful clinical coronary artery bypass operation. Ann Thorac Surg 2000;69:1966-72.

35. Mann FC, Priestley JT, Markowitz JJ, Yater WM. Transplantation of the intact mammalian heart. Arch Surg 1933;26:219-24.

36. Shumacker HB Jr. A surgeon to remember: notes about Vladimir Demikhov. Ann Thorac Surg 1994;58:1196-8.

37. Cooper DK. Experimental development of cardiac transplantation. BMJ 1968;4:174-81.

38. Marcus E, Wong SN, Luisada AA. Homologous heart grafts; transplantation of the heart in dogs. Surg Forum 1951:212-7.

39. Cooper DK. Transplantation of the heart and both lungs. I. Historical review. Thorax 1969;24:383-90.

40. Piciche M, Carpentier A. Dawn and evolution of cardiac procedures. New York; 2013.

41. Webb WR, Howard HS, Neely WA. Practical methods of homologous cardiac transplantation. J Thorac Surg 1959;37:361-6.

42. Cass MH, Brock R. Heart excision and replacement. Guys Hosp Rep 1959;108:285-90.

43. Lower RR, Shumway NE. Studies on orthotopic homotransplantation of the canine heart. Surg Forum 1960;11:18-9.

44. Lower RR, Stofer RC, Shumway NE. Homovital transplantation of the heart. J Thorac Cardiovasc Surg 1961;41:196-204.

45. Reemtsma K, Williamson WE Jr, Iglesias F, Pena E, Sayegh SF, et al. Studies in homologous canine heart transplantation:prolongation of survival with a folic acid antagonist. Surgery 1962;52:127-33.

46. Blumenstock DA, Hechtman HB, Collins JA, Jaretzki A 3rd, Hosbein JD, et al. Prolonged survival of orthotopic homotransplants of the heart in animals treated with methotrexate. J Thorac Cardiovasc Surg 1963;46:616-25.

47. A definition of irreversible coma. Report of the Ad Hoc Committee of the Harvard Medical School to examine the definition of brain death. Jama 1968;205:337-40.

48. Hardy JD, Kurrus FD, Chavez CM, Neely WA, Eraslan S, et al. Heart transplantation in man. Developmental studies and report of a case. Jama 1964;188:1132-40.

49. Kalra A, Seth S, Hote M, Airan B. The story of heart transplantation: from cape town to cape comorin. J Pract Cardiovasc Sci 2016;2:120-5.

50. Barnard CN. The operation. A human cardiac transplant: an interim report of a successful operation performed at Groote Schuur Hospital, Cape Town. S Afr Med J 1967;41:1271-4.

51. Kantrowitz A, Haller JD, Joos H, Cerruti MM, Carstensen HE. Transplantation of the heart in an infant and an adult. Am J Cardiol 1968;22:782-90.

52. Stinson EB, Dong E, Schroeder JS, Harrison DC, Shumway NE. Initial clinical experience with heart transplantation. Am J Cardiol 1968;22:791-803.

53. Cooley DA. In memoriam: Donald N. Ross (1922-2014). Tex Heart Inst J 2014;41:456-7.

54. Cooley DA, Bloodwell RD, Hallman GL, Leachman RD, Nora JJ, et al. Cardiac transplantation: general considerations and results. Ann Surg 1969;169:892-905.

55. Patel R, Terasaki PI. Significance of the positive crossmatch test in kidney transplantation. N Engl J Med 1969;280:735-9.

56. Patterson C, Patterson KB. The history of heart transplantation. Am J Med Sci 1997;314:190-7.

57. DiBardino DJ. The history and development of cardiac transplantation. Tex Heart Inst J 1999;26:198-205.

58. Griepp RB, Stinson EB, Dong E, Clark DA, Shumway NE. Acute rejection of the allografted human heart: diagnosis and treatment. Ann Thorac Surg 1971;12:113-26.

59. Clark DA, Stinson EB, Griepp RB, Schroeder JS, Shumway NE, et al. Cardiac transplantation in man: Vi. prognosis of patients selected for cardiac transplantation. Ann Intern Med 1971;75:15-21.

60. Nishikawa T, Sekiguchi M, Ishibashi-Ueda H. More than 50 years after Konno's development of the endomyocardial biopsy. Int Heart J 2017;58:840-6.

61. Caves PK, Stinson EB, Graham AF, Billingham ME, Grehl TM, et al. Percutaneous transvenous endomyocardial biopsy. JAMA $1973 ; 225: 288-91$. 
62. Melvin KR, Mason JW. Endomyocardial biopsy: its history, techniques and current indications. CMAJ 1982;126:1381-6.

63. Caves P, Billingham M, Stinson E, Shumway N. Serial transvenous biopsy of the transplanted human heart improved management of acute rejection episodes. Lancet 1974;303:821-6.

64. Borel JF, Feurer C, Gubler HU, Stahelin H. Biological effects of cyclosporin A: a new antilymphocytic agent. Agents Actions 1976;6:468-75.

65. Calne RY, White DJG, Rolles K, Smith DP, Herbertson BM. Prolonged survival of pig orthotopic heart grafts treated with cyclosporin A. Lancet 1978;311:1183-5.

66. Morris T. The matter of the heart. London; 2017.

67. Newton C. Interview: Sir Terence English. Bull Roy Coll Surg Engl 2015;97:289-91.

68. English T. Follow your star. Indiana; 2011.

69. Myers BD, Ross J, Newton L, Luetscher J, Perlroth M. Cyclosporine-associated chronic nephropathy. NEJM 1984;311:699-705.

70. Patel JK, Kobashigawa JA. Tacrolimus in heart transplant recipients. BioDrugs 2007;21:139-43.

71. European Multicentre Trial G. Cyclosporin in cadaveric renal transplantation: one-year follow-up of a multicentre trial. Lancet 1983;2:986-9.

72. Starnes VA, Shumway NE. Heart transplantation--Stanford experience. Clin Transpl 1987:7-11

73. Fung JJ. Tacrolimus and transplantation: a decade in review. Transplantation 2004;77:S41-3.

74. Starzl TE, Todo S, Fung J, Demetris AJ, Venkataramman R, et al. FK 506 for liver, kidney, and pancreas transplantation. Lancet 1989;2:1000-4.

75. Jurcevic S, Dunn MJ, Crisp S, Busing K, Rinaldi M, et al. A new enzyme-linked immunosorbent assay to measure anti-endothelial antibodies after cardiac transplantation demonstrates greater inhibition of antibody formation by tacrolimus compared with cyclosporine. Transplantation 1998;65:1197-202.

76. Behr TM, Richter K, Fischer P, Spes CH, Meiser B, et al. Incidence of humoral rejection in heart transplant recipients treated with tacrolimus or cyclosporine A. Transplant Proc 1998;30:1920-1.

77. Wang CH, Ko WJ, Chou NK, Wang SS. Therapeutic drug monitoring of tacrolimus in cardiac transplant recipients: a comparison with cyclosporine neoral. Transplant Proc 2004;36:2386-7.

78. Reichart B, Meiser B, Vigano M, Rinaldi M, Martinelli L, et al. European Multicenter Tacrolimus (FK506) heart pilot study: one-year results--European Tacrolimus Multicenter Heart Study Group. J Heart Lung Transplant 1998;17:775-81.

79. Taylor DO, Barr ML, Radovancevic B, Renlund DG, Mentzer RM Jr, et al. A randomized, multicenter comparison of tacrolimus and cyclosporine immunosuppressive regimens in cardiac transplantation: decreased hyperlipidemia and hypertension with tacrolimus. $\mathrm{J}$ Heart Lung Transplant 1999;18:336-45.

80. Cooney GF, Jeevanandam V, Choudhury S, Feutren G, Mueller EA, et al. Comparative bioavailability of neoral and sandimmune in cardiac transplant recipients over 1 year. Transplant Proc 1998;30:1892-4.

81. Eisen HJ, Hobbs RE, Davis SF, Carrier M, Mancini DM, et al. Safety, tolerability, and efficacy of cyclosporine microemulsion in heart transplant recipients: a randomized, multicenter, double-blind comparison with the oil-based formulation of cyclosporine--results at 24 months after transplantation. Transplantation 2001;71:70-8.

82. Grimm M, Rinaldi M, Yonan NA, Arpesella G, Arizón Del Prado JM, et al. Superior prevention of acute rejection by tacrolimus vs. cyclosporine in heart transplant recipients - a large European trial. Am J Transplant 2006;6:1387-97.

83. Kobashigawa JA, Patel J, Furukawa H, Moriguchi JD, Yeatman L, et al. Five-year results of a randomized, single-center study of tacrolimus vs microemulsion cyclosporine in heart transplant patients. J Heart Lung Transplant 2006;25:434-9.

84. Allison AC, Eugui EM. Mycophenolate mofetil and its mechanisms of action. Immunopharmacology 2000;47:85-118.

85. Eisen HJ, Kobashigawa J, Keogh A, Bourge R, Renlund D, et al. Three-year results of a randomized, double-blind, controlled trial of mycophenolate mofetil versus azathioprine in cardiac transplant recipients. J Heart Lung Transplant 2005;24:517-25.

86. MacKeigan JP, Krueger DA. Differentiating the mTOR inhibitors everolimus and sirolimus in the treatment of tuberous sclerosis complex. Neuro-Oncology 2015;17:1550-9.

87. Kobashigawa JA, Pauly DF, Starling RC, Eisen H, Ross H, et al. Cardiac allograft vasculopathy by intravascular ultrasound in heart transplant patients: substudy from the everolimus versus mycophenolate mofetil randomized, multicenter trial. JACC Heart Fail 2013;1:389-99.

88. Andreassen AK, Andersson B, Gustafsson F, Eiskjaer H, Radegran G, et al. Everolimus initiation and early calcineurin inhibitor withdrawal in heart transplant recipients: a randomized trial. Am J Transplant 2014;14:1828-38.

89. Wlodarczyk Z, Vitko S, Salmela K, Czajkowski Z, Margreiter R. Lipid metabolism in renal transplant patients receiving tacrolimus/ sirolimus combination therapy. Transplant Proc 2005;37:1871-3.

90. Lindenfeld J, Miller GG, Shakar SF, Zolty R, Lowes BD, et al. Drug therapy in the heart transplant recipient: part II: immunosuppressive drugs. Circulation 2004;110:3858-65.

91. Tenderich G, Fuchs U, Zittermann A, Muckelbauer R, Berthold HK, et al. Comparison of sirolimus and everolimus in their effects on blood lipid profiles and haematological parameters in heart transplant recipients. Clin Transplant 2007;21:536-43.

92. Wahlers T. Cytolytic induction therapy in heart and lung transplantation: the protagonist opinion. Transplant Proc 1998;30:1100-3.

93. Odim J, Wheat J, Laks H, Kobashigawa J, Gjertson D, et al. Peri-operative renal function and outcome after orthotopic heart transplantation. J Heart Lung Transplant 2006;25:162-6. 
94. Wahlers T, Cremer J, Fleguth HG, Jurmann M, Herrmann G, et al. Adjusted triple drug immunosuppression and kidney function following heart transplantation. Transplant Proc 1989;21:2492-3.

95. Kobashigawa JA, Miller LW, Russell SD, Ewald GA, Zucker MJ, et al. Tacrolimus with mycophenolate mofetil (MMF) or sirolimus vs. cyclosporine with MMF in cardiac transplant patients: 1-year report. Am J Transplant 2006;6:1377-86.

96. Kobashigawa J, Ross H, Bara C, Delgado JF, Dengler T, et al. Everolimus is associated with a reduced incidence of cytomegalovirus infection following de novo cardiac transplantation. Transpl Infect Dis 2013;15:150-62.

97. Euvrard S, Boissonnat P, Roussoulières A, Kanitakis J, Decullier E, et al. Effect of everolimus on skin cancers in calcineurin inhihitortreated heart transplant recipients. Transpl Int 2010;23:855-7.

98. Eisen HJ, Kobashigawa J, Starling RC, Pauly DF, Kfoury A, et al. Everolimus versus mycophenolate mofetil in heart transplantation: a randomized, multicenter trial. Am J Transplant 2013;13:1203-16.

99. Mehra MR, Canter CE, Hannan MM, Semigran MJ, Uber PA, et al. The 2016 international society for heart lung transplantation listing criteria for heart transplantation: a 10-year update. J Heart Lung Transplant 2016;35:1-23.

100. Ponikowski P, Voors AA, Anker SD, Bueno H, Cleland JGF, et al. 2016 ESC guidelines for the diagnosis and treatment of acute and chronic heart failure: the task force for the diagnosis and treatment of acute and chronic heart failure of the European Society of Cardiology (ESC) developed with the special contribution of the Heart Failure Association (HFA) of the ESC. Eur Heart J 2016;37:2129-200.

101. Yancy CW, Jessup M, Bozkurt B, Butler J, Casey DE Jr, et al. 2016 ACC/AHA/HFSA focused update on new pharmacological therapy for heart failure: an update of the $2013 \mathrm{ACCF} / \mathrm{AHA}$ guideline for the management of heart failure: a report of the American College of Cardiology/American Heart Association Task Force on clinical practice guidelines and the Heart Failure Society of America. Circulation 2016;134:e282-93.

102. Dorent R, Gandjbakhch E, Goéminne C, Ivanes F, Sebbag L, et al. Assessment of potential heart donors: a statement from the French heart transplant community. Arch Cardiovasc Dis 2017; doi: 10.1016/j.acvd.2017.12.001.

103. Copeland JG. Only optimal donors should be accepted for heart transplantation: protagonist. J Heart Lung Transplant 1995;14:1038-42.

104. Brock MV, Salazar JD, Cameron DE, Baumgartner WA, Conte JV. The changing profile of the cardiac donor. J Heart Lung Transplant 2001;20:1005-9.

105. NHS Blood and Transplant. Transplant Activity in the UK, 2016-2017. NHS Blood and Transplant; 2017.

106. Cooper DK, Keogh AM, Brink J, Corris PA, Klepetko W, et al. Report of the Xenotransplantation Advisory Committee of the International Society for Heart and Lung Transplantation: the present status of xenotransplantation and its potential role in the treatment of end-stage cardiac and pulmonary diseases. J Heart Lung Transplant 2000;19:1125-65.

107. Thompson JF, Wood RF, Cahill AP, Franklin PM, Morris PJ. Kidney transplantation and seat belt legislation. BMJ (Clinical research ed) 1983;287:1260-1.

108. Calil AM, Sallum EA, Domingues Cde A, Nogueira Lde S. Mapping injuries in traffic accident victims: a literature review. Rev Lat Am Enfermagem 2009;17:120-5.

109. Mercer P, Sharples L, Edmunds J, Gittins R, Baines J, et al. Evaluating the donor pool: impact of using hearts from donors over the age of 49 years. Transplant Proc 1997;29:3293-6.

110. Young JB. Age before beauty: the use of "older" donor hearts for cardiac transplantation. J Heart Lung Transplant 1999;18:488-91.

111. Silva SFR, Silva SL, Nascimento AC, Parente MM, Albuquerque CA, et al. Profile of organ donors in Ceará, northeastern Brazil, from 1998 to 2012. Transplant Proc 2014;46:1692-4.

112. Rodrigues SdLL, Ferraz Neto JB-HdE, Sardinha LAdC, Araujo S, Zambelli HJL, et al. Profile of effective donors from organ and tissue procurement services. Rev Bras Ter Intensiva 2014;26:21-7.

113. Drinkwater DC, Laks H, Blitz A, Kobashigawa J, Sabad A, et al. Outcomes of patients undergoing transplantation with older donor hearts. J Heart Lung Transplant 1996;15:684-91.

114. Bennett LE, Edwards EB, Hosenpud JD. Transplantation with older donor hearts for presumed "stable" recipients: an analysis of the Joint International Society for Heart and Lung Transplantation/United Network for Organ Sharing Thoracic Registry. J Heart Lung Transplant 1998; 17:901-5.

115. Massad MG, Smedira NG, Hobbs RE, Hoercher K, Vandervoort P, et al. Bench repair of donor mitral valve before heart transplantation. Ann Thorac Surg 1996;61:1833-5.

116. Marelli D, Laks H, Fazio D, Moore S, Moriguchi J, et al. The use of donor hearts with left ventricular hypertrophy. J Heart Lung Transplant 2000;19:496-503.

117. Hornik L, Tenderich G, Wlost S, Zittermann A, Minami K, et al. Organs from donors with primary brain malignancy: the fate of cardiac allograft recipients. Transplant Proc 2004;36:3133-7.

118. Banner NR, Bonser RS, Clark AL, Clark S, Cowburn PJ, et al. UK guidelines for referral and assessment of adults for heart transplantation. Heart 2011;97:1520-7.

119. Stewart GC, Mehra MR. A history of devices as an alternative to heart transplantation. Heart Fail Clin 2014;10:S1-12.

120. Wilhelm MJ. Long-term outcome following heart transplantation: current perspective. J Thorac Dis 2015;7:549-51.

121. Lund LH, Edwards LB, Kucheryavaya AY, Benden C, Christie JD, et al. The registry of the international society for heart and lung transplantation: thirty-first official adult heart transplant report--2014; focus theme: retransplantation. J Heart Lung Transplant 2014;33:996-1008. 
122. Burchill LJ. Heart transplantation in adult congenital heart disease. Heart 2016;102:1871-7.

123. Lund LH, Edwards LB, Dipchand AI, Goldfarb S, Kucheryavaya AY, et al. The registry of the International Society for Heart and Lung Transplantation: thirty-third adult heart transplantation report-2016; focus theme: primary diagnostic indications for transplant. J Heart Lung Transplant 2016;35:1158-69. 